\title{
PERAN PEMERINTAH DALAM DISTRIBUSI TANAH ATAU LAHAN PERKEBUNAN \\ (Studi Literatur Pemikiran Ekonomi Islam Perspektif Abu 'Ubaid Al-Qasim Bin Salam)
}

\author{
Irawati \\ (Alumni STEI SEBI) \\ $\&$ \\ Adril Hakim \\ (Dosen STEI SEBI)
}

\begin{abstract}
With the development and welfare reasons, the government diverts thousands hectare civil's gardens for the sake of oil palm plantation development. Beside the unfair handing the Ulayat land mechanism, the switch function of productive agricultural lands led to growing economic inequality which lead to the conflict. Therefore, the thought of Abu Ubaid in the book of al-Amwal regarding the law and politics in the land or plantations as a benchmark in achieving solution upon the issue. The research question in this study namely: How does the view of Abu 'Ubaid about the government's role in the distribution and management of plantations? and what kind of policies is needed, so it can effectively decrease the gaps in the current farm/land owner?. The methodology in this present study used descriptive research which is library-based research. The data were analyzed qualitatively. Data used in this study is qualitative data obtained from an authentic source comprising a source of primary data and secondary data sources. The results show that that the law and the way of Abu 'Ubaid provide a solution to the inequality of land ownership is very different from the government policy in Indonesia. One of the policy which is to clarify over the abandoned land by tenants is for three years and then the government takes the right for the land. The government has the authority to give the land to a new tenant who wants to turn the land becomes more productive.
\end{abstract}

Keywords: Goverment. Land or Farming, Abu 'Ubaid Al-Qasim bin Salam

\section{PENDAHULUAN}

Indonesia merupakan negara yang memiliki kekayaan alam dan keindahan alam yang begitu menakjubkan. Jika dilihat dari sudut pandang kekayaan yang dimiliki negara ini maka mustahil penduduk atau rakyat Indonesia hidup dalam kemiskinan, keterbelakangan ekonomi, angka kriminalitas tinggi dan akses negatif lainnya yang mengarah pada 
kesan ketidakberdayaan atau menggambarkan kehidupan masyarakat yang kurang maju.

Pada tahun 2012 tidak ada perubahan yang signifikan pada negara yang kita cintai ini, Jumlah Penduduk Miskin yang berada di kota $10,647.20$ sedangkan yang berada didesa $18,485.20$, persentase penduduk miskin di kota $8.78 \%$ sedangkan di desa $15.12 \%$, kemudian dilihat dari sudut Indeks Keparahan Kemiskinan di kota $0.36 \%$ sedangkan di desa $0.59 \%$. Penduduk yang hidup dibawah garis kemiskinan mencapai 248,707, data ini diambil pada tahun 2012 menurut data provinsi (www.bps.go.id). Adanya perbedaan yang sangat besar dapat kita lihat antara penduduk yang tinggal di desa dengan penduduk yang tinggal di daerah kota, penduduk yang tinggal di desa sangat membutuhkan infrastruktur baik itu jembatan, irigasi untuk pertanian, jalanan sebagai perantara distribusi barang hasil pertanian yang harus diperbaiki dan masih banyak lainnya yang belum didapat oleh penduduk di desa-desa terpencil di Indonesia. Akibatnya banyak yang melakukan urbanisasi dengan tujuan mendapatkan pekerjaan dan hidup lebih sejahtera, namun tidak banyak yang mengalami kegagalan setelah sampai di kota dan kehidupannya menjadi tambah parah.

Indonesia dikenal dengan negara agraris karena sebagian besar penduduk Indonesia (hampir 50\%) bekerja dibidang pertanian. Luas tanah dan kesuburan tanah serta iklim tropis di negara ini menjadikan sektor pertanian sebagai inti penting dari pembangunan ekonomi. Oleh karena itu pemerintah seharusnya tanggap cepat dalam memikirkan berbagai permasalahan dalam ekonomi pertanian demi mewujudkan kesejahteraan masyarakat Indonesia.

Menurut Aviliani anggota Komite Ekonomi Nasional (KEN), pertumbuhan agribisnis masih di bawah 5\%, bahkan mencapai 3,37\% akibat beberapa masalah yang melekat di sektor pertanian. Pada tahun 2012, berbagai masalah masih melanda petani dan masyarakat pedesaan. Seperti masalah akses dan kontrol atas tanah, air, benih, konflik agraria, belum adanya perlindungan harga produk pertanian bagi para petani kecil serta serbuan pangan impor murah yang menyebabkan anjloknya harga produk pertanian dalam negeri. 


\section{Gambar 1.1 Konflik Pada Sektor Pertanian}

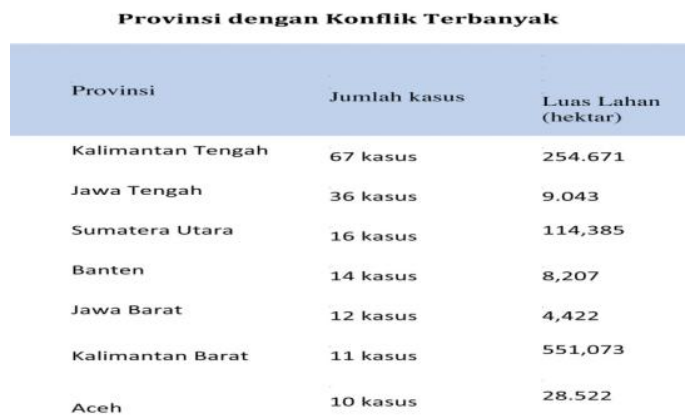

Sumber : www.bps.go.id

Dapat kita lihat pada gambar.1 bahwa konflik pada sektor pertanian tertinggi berada di daerah kalimantan tengah dengan 67 kasus dengan luas lahan 254.671 ha. Kemudian konflik terendah ada di daerah aceh yang hanya 10 kasus dengan luas lahan 28.522 ha. Namun yang menjadi fokus penulis adalah pada daerah sumatera utara terjadi 16 kasus dengan luas lahan 114,385 ha, beberapa konflik di Sumatera Utara masih berkepanjangan sampai saat ini dan belum mendapatkan solusinya.

Pada tahun 2009 dikeluarkan keputusan bersama antara Ketua Badan Pertanahan Nasional (BPN) dan KAPOLRI tentang Penanganan Konflik Agraria. Namun, dua tahun kemudian bara konflik terbakar, insiden Mesuji, Lampung dan Sumsel di antara ratusan insiden lainnya. Walhasil, petugas malah terlibat, karena sistem pengamanan perusahaanperusahaan yang berkonflik itu menggunakan jasa aparat, preman dan pamswakarsa.

Pada Pidato Presiden 31 Januari 2007 Susilo Bambang Yudhoyono (SBY) sempat mengumbar janji untuk menjalankan program reforma agraria secara bertahap," "Program Reforma Agraria secara bertahap akan dilaksanakan mulai tahun 2007 ini. Langkah itu dilakukan dengan mengalokasikan tanah bagi rakyat termiskin yang berasal dari hutan konversi dan tanah lain yang menurut hukum pertanahan kita boleh diperuntukkan bagi kepentingan rakyat. Inilah yang saya sebut sebagai prinsip Tanah untuk Keadilan dan Kesejahteraan Rakyat yang saya anggap mutlak untuk dilakukan." Redistribusi lahan untuk petani yang dikampanyekan oleh SBY ternyata hanya sebatas retorika. Rakyat diusir dari tanahnya dan secara data, tak ada lagi tanah tersisa untuk rakyat. Kalaupun ada, tanah-tanah bekas perkebunan itu rata-rata sudah kering. Lantas tanah yang mana untuk Rakyat. 
Dalam kasus lain, area lahan yang menjadi hak perusahaan itu dibiarkan terlantar dan kosong. Karena melihat bahwa lahan itu kosong, lalu orang-orang pun berdatangan menggarapnya karena desakan kebutuhan hidup. Di satu sisi karena merasa lahan itu adalah haknya, perusahaan pun melakukan penertiban atau meminta pemerintah melakukan penertiban. Perusahan berlindung di balik Undang-Undang Nomor 18 tahun 2004 tentang Perkebunan. Undang-undang ini memberikan legalitas yang kuat kepada perusahaan-perusahaan perkebunan untuk mengambil tanah-tanah yang dikuasai rakyat.

Konflik pun pecah antara mereka yang menggarap dan menguasai tanah itu termasuk pemilik hak ulayat dengan perusahaan dan pemerintah. Atas nama Undang-Undang, aparat keamanan diterjunkan. Pasalnya, Undang-Undang mengharuskan negara memberikan perlindungan keamanan dan jaminan berjalannya operasi perusahaan atas nama investasi. Apalagi kadang kala perusahaan memberikan dana untuk mendukung pengamanan atau penertiban itu.

Di sinilah akhirnya terlihat keberpihakan aparat (negara) kepada pemilik modal (investor) dengan alasan sesuai amanat Undang-Undang investasi. Dalam melaksanakan itu, aparat sering kali menggunakan pendekatan represif. Akibatnya terjadilah bentrokan dan kekerasan oleh aparat (negara) terhadap rakyatnya sendiri. Semuanya demi menjamin dan melindungi kepentingan investor pemilik modal. Jadilah, aparat atau negara akhirnya menjadi berhadap-hadapan dengan rakyatnya sendiri.

Rangkaian berbagai konflik tidak bisa diharapkan bisa diselesaikan dengan Rancangan Undang-Undang (RUU) Penanganan Konflik yang sedang dibahas. Sebab, RUU tersebut hanya berorientasi pada penanganan konflik (conflict manifest), tetapi belum memuat proses pengelolaan konflik (conflict management) secara utuh menyeluruh. RUU ini juga belum menyentuh akar persoalan sebenarnya, yaitu UndangUndang bercorak liberal yang lebih berpihak kepada kepentingan pemilik modal dengan mengorbankan hak dan kepentingan rakyat.

Semua ini tidak bisa dilepaskan dari sistem kapitalisme yang diterapkan di Indonesia. Sistem itu melahirkan corporation state berupa hubungan simbiosis mutualisme antara elit politik dan bisnis yang merugikan rakyat banyak. Sistem demokrasi yang menjadi pilar pokok ideologi kapitalisme ini kemudian menjadi alat legitimasi lahirnya Undang-Undang liberal.

Tanpa persetujuan, tanah-tanah adat, kebun dan pemukiman direbut perusahaan. Rakyat yang hanya butuh hidup tenang dan menanam singkong bergelimpangan menyetor nyawa. HuMa (Hukum berbasis 
Masyarakat) mencatat 108 konflik di 10 propinsi, Sawit Watch mencatat 663 Konflik Perkebunan, BPN bahkan mencatat lebih dari 8000 konflik agraria di Indonesia. Birokrasi agraria terbukti membela Kaum bermodal, karena semua lebih manut isi kantong, di banding isi perut rakyat.

Dalam enam tahun terakhir, HuMa (Hukum berbasis Masyarakat) mencatat konflik agraria dan Sumber Daya Alam (SDA) di Indonesia, terjadi menyebar di 98 kota dan kabupaten di 22 provinsi. Luasan area konflik mencapai 2.043.287 hektar atau lebih dari 20 ribu kilometer persegi alias setara separuh Sumatera Barat. Penyumbang konflik terbesar sektor perkebunan dan kehutanan, mengalahkan kasus pertanahan atau agraria non kawasan hutan dan non kebun. Sektor perkebunan 119 kasus, dengan luasan area mencapai 413.972 hektar, sedang sektor kehutanan 72 kasus, dengan luas area mencapai 1, 2 juta hektar lebih.

Penyebab konflik ini, menurut Hukum berbasis Masyarakat (HuMa), terkait kepentingan para pihak seperti pemerintah dinilai lebih memprioritaskan pemilik modal besar, keinginan mengembangkan komoditas tertentu seperti sawit, kapas transgenik, ekaliptus, dan lainlain. Lalu, konflik ruang tidak hanya terjadi antara masyarakat dengan pemilik modal, juga pemilik modal dengan pemilik modal lain, pola kerjasama tidak seimbang antara perusahaan dengan petani dan penentuan pola ruang tidak partisipatif. Dari data HuMa, paling tidak ada 14 provinsi memiliki konflik perkebunan mayoritas di Kalimantan dan Sumatera.

Pada tahun 2012 sejumlah kebijakan strategis pemerintah disektor pangan dan pertanian dikeluarkan, ditengah kondisi sistem pertanahan Indonesia yang pelik tidak membuat pemerintah batal dalam mengeluarkan Undang-Undang No 2 Tahun 2012 tentang pengadaan tanah bagi pembangunan untuk kepentingan umum yang semakin menambah tumpang tindih aturan pertanahan dan berpotensi besar meningkatkan konflik agraria. Di tahun yang sama, pembahasan panjang revisi Undang-Undang No 7 Tahun 1996 dituntaskan dengan dikeluarkannya Undang-Undang pangan baru No 18 Tahun 2012.

Menurut Henry Saragih ketua umum Serikat Petani Indonesia (SPI) Undang-Undang baru tersebut justru melemahkan semangat kedaulatan pangan SPI dan organisasi rakyat lainnya, sejumlah pasal dalam Undang-Undang baru tersebut yang justru semakin memberi ruang yang luas pada perusahaan pangan dan agribisnis untuk mengelola sektor pangan dan pertanian yang menjadi hajat orang banyak.

Peraturan baru tersebut juga belum mampu membendung arus impor pangan yang semakin besar. Berbagai komoditas pangan tidak sesuai target pencapaiannya. Tahun ini ketergantungan pada impor 
sejumlah komoditas seperti kedelai, singkong, dan gandum telah menyebabkan gejolak yang cukup besar baik ditingkat konsumen maupun produsen kecil.

Untuk mengatasi berbagai masalah diatas perlunya peran pemerintah yang lebih serius dalam memikirkan strategi dan sistem perekonomian di Indonesia. Berbagai gejolak ekonomi pertanian di Indonesia baik individu maupun kelompok, pembangunan dari sudut infrastruktur terus berkembag namun permasalahan ekonomi pertanian seperti konflik atas kepemilikan lahan, alih fungsi lahan pertanian atau konversi lahan tidak dapat terselesaikan. Sebuah negara tidak hanya melihat pada bagaimana mendapatkan laju pertumbuhan yang tinggi dalam output agregat, namun pemerintah yang bertugas menata negara yang sejahtera juga harus mampu mengurangi secara substansial ketidakseimbangan ekonomi makro dan kesenjangan ekonomi, karena semua manusia memiliki hak untuk hidup bahagia.

Indonesia merupakan salah satu negara yang penduduknya mayoritas ummat muslim. Secara historis, ummat muslim pernah menjadi acuan dalam pemikiran ekonomi dunia karena bisa menciptakan perekonomian yang stabil sehingga terhindar dari inflasi dan spekulasi. Pemikiran ekonomi Islam lahir dari kenyataan bahwa Islam adalah sistem yang diturunkan Allah kepada seluruh manusia untuk menata seluruh aspek kehidupannya dalam seluruh ruag dan waktu. Tidak satupun masalah atau aspek yang terkait dengan kehidupan manusia, langsung atau tidak langsung, dan dibutuhkan oleh manusia, melainkan Islam telah memberikan penjelasan tertentu tentang masalah atau aspek itu (Izzan \& Tanjung, 2006, hal. 1). Pemikiran ekonomi Islam sebenarnya sudah ada sejak munculnya Islam itu sendiri. Namun sebagian besar diskusi-diskusi ekonomi Islam terkubur dalam literatur-literatur kitab klasik (Majid, 2003, hal. 3).

Sungguh disayangkan pemikiran-pemikiran ekonomi Islam dikesampingkan di negara yang mayoritas umat muslim ini, dan sebagian orang masih menganggap bahwa Islam sebagai hambatan dalam pembangunan ekonomi. Meskipun pandanga ini berasal dari para pemikir barat, tidak sedikit juga intelektual Muslim yang meyakininya. Mereka memandang Islam sebagai suatu agama yang terisolasi oleh masalahmasalah ritual, bukan sebagai suatu sistem yang komprehensif yang mencakup seluruh aspek kehidupan termasuk di dalamnya pembangunan ekonomi.

Tercatat dalam sejarah perkembangan ilmu pengetahuan Islam, para ulama dan sarjana muslim pada era klasik telah banyak menulis dan 
mengkaji ekonomi Islam tidak saja secara normatif, tetapi juga secara empiris dan ilmiah dengan metedologi yang sistematis (Huda \& Muti, 2011, hal. 2). Abu 'Ubaid merupakan seorang ahli hadits (muhaddits) dan ahli fiqh (fuqaha) terkemuka di masa hidupnya yang menetapkan revitalisasi sistem perekonomian berdasarkan Al-qur'an dan Hadits melalui reformasi dasar-dasar kebijakan keuangan dan institusinya. Ia diangkat sebagai seorang qadi (hakim) di masa pemerintahan Harun ArRasyid di Tarsus hingga tahun $210 \mathrm{H}$, slama menjabat sebagai qadi, ia sering menangani berbagai kasus pertahanan dan perpajakan serta menyelesaikan dengan baik. Alih bahasa yang dilakukannya terhadap kata-kata dari bahasa Arab juga menunjukkan bahwa Abu 'Ubaid sedikit banyak menguasai bahasa tersebut.

Secara umum, pada masa hidup Abu 'Ubaid, pertanian dipandang sebagai sektor usaha yang paling baik dan utama karena menyediakan keutuhan dasar, makanan dan juga merupakan sumber utama pendapatan negara. Hal ini menjadikan masalah perbaikan sektor pertanian menjadi isu utama, bukan masalah pertumbuhan ekonomi dalam pengertian modern, oleh karena itu, Abu 'Ubaid mengarahkan sasarannya pada persoalan legitimasi sosio-politik-ekonomi yang stabil dan adil.

Jika isi kitab Al-Amwaal dievaluasi dari sisi filosofi hukum, akan tampak bahwa Abu 'Ubaid menekankan keadilan sebagai prinsip utama. Bagi Abu 'Ubaid, pengimplementasian dari prinsip-prinsip ini akan membawa kepada kesejahteraan ekonomi dan keselarasan sosial (AlQasim, 2009, hal. 8). Dengan kata lain. Abu 'Ubaid ingin menyatakan bahwa segala kebijakan yang hanya menguntungkan sekelompok masyarakat dan membebani sekelompok masyarakat lainnya harus dihindari negara semaksimal mungkin. Pemerintah harus mengatur harta kekayaan negara agar selalu dimanfaatkan demi kepentingan bersama dan mengawasi hak kepemilikan pribadi agar tidak disalahgunakan sehingga mengganggu atau mengurangi manfaat bagi masyarakat umum.

Pandangan-pandangan Abu 'Ubaid juga merefleksikan perlunya memelihara dan mempertahankan keseimbangan antara hak dan kewajiban masyarakat serta menekankan esprit de corps, rasa persatuan dan tanggung jawab bersama. Abu 'Ubaid juga dengan tegas menyatakan bahwa pemerintah wajib memberikan jaminan standar kehidupan yang layak bagi setiap individu dalam sebuah masyarakat muslim (Al-Qasim, 2009, hal. 15).

Beberapa pandangan Abu 'Ubaid didalam kita al-amwal yang mencakup pertanian, perpajakan, zakat dan hukum sosial-politik, penulis merasa tertarik untuk mengkaji lebih jauh pemikiran Abu 'Ubaid al- 
Qasim bin Salam yang lebih terkhusus kepada pemikirannya mengenai peran pemerintah dalam distribusi lahan perkebunan. Mengingat sengketa lahan perkebunan di Sumatera terus meningkat dari tahun ke tahun dan tidak kunjung mendapat solusi, bahkan sengketa tersebut tidak segan menimbulkan korban jiwa.

\section{Tinjauan pustaka}

\subsection{Peran Dan Fungsi Pemerintah Indonesia Dalam Distribusi Tanah Atau Lahan Perkebunan}

Sejak Indonesia merdeka sudah terlihat bahwa pemerintah memegang peranan besar dalam perekonomian. Hal tersebut tercantum secara eksplisit dalam Undang-Undang Dasar 1945 pasal 33 ayat 2 dan ayat 3, yang bunyinya; "cabang-cabang produksi yang penting bagi negara dan yang menguasai hajat hidup orang banyak dikuasai oleh negara" (ayat 2), "bumi, air, dan kekayaan alam yang terkandung didalamnya dikuasai oleh negara, dan dipergunakan untuk sebesarbesarnya kemakmuran rakyat"(ayat 3) (Arifin, 2005, hal. 78).

Kebijakan deregulasi terus digulirkan sebagai usaha untuk memerangi inefisiensi dan upaya mendukung strategi menoleh keluar. Ini merupakan bukti bahwa sebagian kalangan di dalam pemerintah pada saat itu cukup tanggap terhadap pentingnya kebijakan-kebijakan yang rasional. Mekanisme pasar yang efektif ingin dikembalikan ke tengahtengah sistem ekonomi sebagai penggerak pembangunan sehingga sasaran pertumbuhan dan target ekspor bisa dicapai (Rachbini, 2004, hal. 110).

Tingkat produksi perkebunan sekarang yang masih rendah menjadi fokus peran pemerintah dalam mendistribusikan luas tanah minimum dan maksimum bagi tiap-tiap keluarga tani, menjadi salah satu dasar penentuan batas-batas minimum dan maksimum tanah yang berbeda dengan waktu yang akan datang. Jika produksi perkebunan meningkat dua kali lipat dalam masa sekarang ini maka pemerintah harus meninjau kembali batas-batas yang ditentukan di waktu beberapa tahun sebelumnya.

Menurut Achmad Ya'kub (Ketua Departemen Kajian Strategis Nasional Serikat Petani Indonesia), dalam hal pertanahan setidaknya pemerintah harus mengambil langkah-langkah berikut: Pertama, pemerintah harus bersungguh-sungguh menjalankan Pembaruan Agraria yang berpihak kepada petani. Hal itu dapat dilakukan dengan menjadikan tanah-tanah yang dikuasai perusahaan-perusahaan perkebunan dan kehutanan, sebagai tanah obyek landreform. 
Kemudian saat ini di Indonesia masih terdapat 12.418.056 hektar tanah terlantar yang jika didistribusikan akan sangat bermanfaat bagi keluarga-keluarga tani. Pendistribusian ini hendaknya mengutamakan keluarga tani yang tak bertanah, buruh tani, dan petani-petani kecil dengan kepemilikan tanah kurang dari 0,5 hektar. Jika rata-rata satu keluarga tani mendapatkan 2 hektar tanah untuk digarap, sesuai pasal 8 Perpu No.56/1960 untuk batas minimum yang dapat menjamin kelangsungan hidup keluarga, maka terdapat 6.209.028 keluarga yang akan mendapatkan sumber penghidupan yang layak, disamping untuk memenuhi kebutuhan pangan dan produk pertanian nasional. Kedua, pemerintah tidak melakukan alih fungsi lahan-lahan subur yang digunakan untuk pertanian menjadi peruntukkan lain di luar sektor pertanian, terutama yang tidak menguntungkan bagi rakyat banyak. Serta pembatasan modal asing dalam pengelolaan sumber daya agraria, pemerintah mengatur kembali atau mencabut undang-undang sektoral yang saling bertabrakan dan tidak menguntungkan rakyat dan negara Indonesia, seperti UU Perkebunan No.18/2004 (www.indoprogress.com).

\subsection{Konsep Bank Tanah di Indonesia}

Penyelenggaraan bank tanah seharusnya berbentuk badan hukum publik, karena kegiatan lembaga bank tanah termasuk dalam kebijakan yang didasarkan pada pasal 33 ayat 3 Undang-Undang Dasar 1945.

Jika bank tanah berpegang pada bunyi pasal 18 UUPA dan pasal 1 UU No.20 Tahun 1961 tentang pencabutan hak atas tanah dan bendabenda yang berada di atasnya yang menganut pendekatan berupa general guideline untuk pengertian kepentingan umum, maka mengenai kegiatan bank tanah umum yang tujuan pokoknya adalah untuk mengatur penggunaan tanah dan mengatur harga tanah yang secara tidak langsung ditujukan untuk kepentingan rakya serta kepentingan pembangunan, maka kiranya bila cara jual beli mengalami kegagalan, dapat dilakukan cara pencabutan hak atas tanah.

Lembaga bank tanah dapat memperoleh tanah melalui jual beli, pengadaan tanah/pencabutan hak atas tanah, dan cara-cara lain, misalnya tukar-menukar atau perolehan melalui atau sebagai akibat penelantaran tanah. Yang menjadi masalah adalah, cara manakah yang tepat untuk diterapkan oleh lembaga bank tanah itu mengingat bahwa secara garis besar lembaga bank tanah dapat dibagi menjadi dua kriteria, yakni bank tanah umum (general land banking) dan bank tanah khusus (spesial land banking) (Sumardjono, 2008, hal. 230). 
Di Swedia dan Belanda, kegiatan lembaga bank tanah lebih bersifat umum, sedangkan di Amerika Serikat yang lebih menonjol justru kegiatan lembaga bank tanah khusus (skalanya lebih terbatas). Walaupun terdapat tujuan lembaga bank tanah, namun pada umumnya prioritas diletakkan di antara mengarahkan pengembangan penggunaan tanah dan mempengaruhi harga tanah.

Intensitas pembangunan yang semakin meningkat dan kondisi keterbatasan persediaan tanah berakibat semakin sulitnya memperoleh tanah untuk berbagai keperluan, baik yang akan dialokasikan bagi pelaksanaan pembangunan untuk kepentingan umum maupun bagi pelaksanaan pembangunan untuk kepentingan perusahaan/ swasta. Selain itu pertambahan jumlah penduduk, kelangkaan tanah dan kemunduran kualitas tanah, alih fungsi penggunaan/peruntukan tanah serta semakin meningkatnya konflik pertanahan, kemiskinan, sempitnya lapangan kerja, terdesaknya hak-hak masyarakat hukum adat, dan lain sebagainya mendesak agar Pemerintah menata ulang berbagai kebijakan di bidang pertanahan.

Kondisi di atas, dihadapkan lagi dengan melonjaknya harga tanah yang secara tidak terkendali/wajar dari tahun ke tahun untuk berbagai kepentingan. Bahkan ada kecenderungan penguasaan tanah dalam skala luas ditujukan untuk mencari keuntungan dengan berkedok sebagai badan usaha yang bergerak di bidang properti dengan Hak Guna Bangunan (HGB) dan bidang perkebunan dengan Hak Guna Usaha (HGU) serta sebagai badan usaha yang bergerak dalam penyiapan tanah untuk kawasan perindustrian dengan regulasi Lingkungan Siap Bangun (Lisiba) dan Kawasan Siap Bangun (Kasiba). (Sutaryono.Ruang diskusi kritis manajemen pertanahan dan penataan ruang.Desember.2013)

Intensitas pembangunan yang semakin meningkat dan keterbatasan persediaan tanah membawa dampak semakin sulitnya memperoleh tanah untuk berbagai keperluan terutama dalam perkebunan. Melonjaknya harga tanah secara tidak terkendali, dan kecendrungan perkembangan penggunaan tanah secara tidak teratur. Hal ini menimbulkan gagasan untuk membentuk lembaga bank tanah yang muncul pada tahun 1980-an dan mendapat penegasan kembali oleh presiden bulan septempber tahun 1993.

Secara umum bank tanah dimaksudkan sebagai setiap kegiatan pemerintah untuk menyediakan tanah, yang akan dialokasikan penggunaannya di kemudian hari (Maria, 2001, hal. 7-8). 


\subsection{Konsep Reforma Agraria}

Jika dilihat dari politik pertanahan di Indonesia, salah satu politik pertanahan yang sangat strategis untuk mencegah/mengurangi konflik pertanahan adalah reforma agraria (landreform). Konsep reforma (pembaharuan) agraria pada hakikatnya merupakan konsep landreform yang dilengkapi dengan konsep access reform dan konsep legal / regulation reform. Konsep landreform adalah penataan kembali struktur penguasaan kepemilikan tanah yang lebih adil, termasuk pencegahan konsentrasi kepemilikan tanah. Konsep access reform berkaitan dengan penataan penggunaan atau pemanfaatan tanah yang lebih produktif disertai penataan dukungan sarana dan prasarana yang memungkinkan petani memperoleh akses ke sumber ekonomi di wilayah pedesaan seperti akses sarana dan prasarana pertanian, pengairan, jalan usaha tani, pemasara produksi, koperasi usaha tani, dan perbankan (kredit usaha rakyat). Sementara konsep policy/ regulation reform berkenaan dengan pengaturan kebijakan dan hukum yang berpihak pada rakyat banyak (Limbong, 2012, hal. 372).

Reforma Agraria merupakan implementasi dari mandat Ketetapan Majelis Permusyawaratan Rakyat Republik Indonesia (TAP MPR RI), Nomor IX/MPR/2001 Tentang Pembaruan Agraria dan Pengelolaan Sumberdaya Alam dan Keputusan MPR RI Nomor 5/MPR/2003 tentang Penugasan kepada MPR-RI untuk Menyampaikan Saran atas Laporan Pelaksanaan Keputusan MPR-RI oleh Presiden, DPR, BPK dan MA pada Sidang Tahunan MPR-RI Tahun 2003. Salah satu butir saran dimaksud kepada Presiden Republik Indonesia, terkait dengan perlunya Penataan Struktur Penguasaan, Pemilikan, Pemanfaatan dan Penggunaan Tanah (www.bpn.go.id).

Dalam tataran operasional Reforma Agraria di Indonesia dilaksanakan melalui 2 (dua) langkah yaitu; pertama, penataan kembali sistem politik dan hukum pertanahan berdasarkan Pancasila, UndangUndang Dasar 1945 dan Undang-Undsang Pokok Agraria (UUPA). Dan kedua, Proses Penyelenggaraan Land Reform Plus, yaitu penataan aset tanah bagi masyarakat dan Penataan akses masyarakat terhadap sumbersumber ekonomi dan politik yang memungkinkan masyarakat untuk memanfaatkan tanahnya secara baik. Di dalam penyelenggaraan Land Reform Plus diselenggarakan dua hal penting yaitu Aset Reform dan Akses Reform. 


\subsection{Konsep Sertifikasi Tanah Petani}

Sertifikat Tanah Petani adalah sub komponen dari komponen kegiatan legalisasi aset (Legalisasi aset adalah proses administrasi pertanahan yang meliputi adjudikasi (pengumpulan data fisik, data yuridis, pengumuman serta penetapan dan/ atau penerbitan surat keputusan pemberian hak atas tanah), pendaftaran hak atas tanah serta penerbitan sertipikat hak atas tanah. Kegiatan ini diselenggarakan oleh Badan Pertanahan Nasional Republik Indonesia untuk melegalisasi (mensertifikasi) aset berupa tanah belum bersertifikat milik (yang telah dimiliki/dikuasai) oleh perorangan anggota masyarakat atau perorangan anggota kelompok masyarakat tertentu).

\section{Gambar 4.2 Jumlah Bidang Tanah Bersertifikat per Jenis Hak}

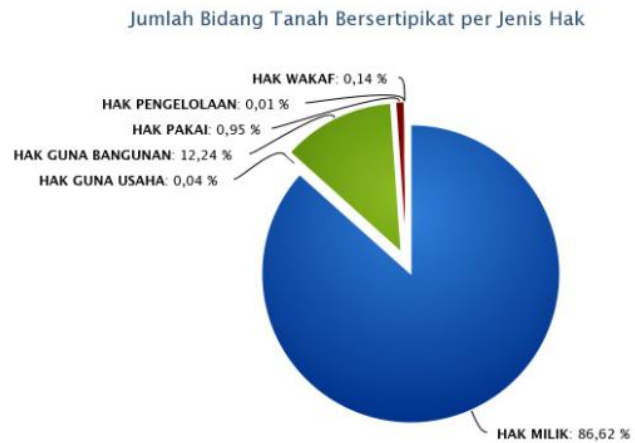

Sumber : $\underline{w w w . b p n . c o . i d}$

Gambar diatas menunjukkan jumlah bidang tanah yang telah tersertifikat per jenis hak, menurut Badan Pertanahan Nasional dilihat dari per jenis hak jumlah bidang tanah dikuasai oleh sebagian besar hak milik yaitu 86,62 \% sedangkan hak pengelolaan hanya $0,01 \%$ disini dapat kita simpulkan bahwa program sertipikasi menurut jumlah bidang tanah belum berjalan lancar karena hak milik lebih banyak memiliki sertipikasinya dibanding hak-hak lainnya. 


\section{Gambar 4.3 Jumlah Bidang Tanah Bersertifikat per Tahun}

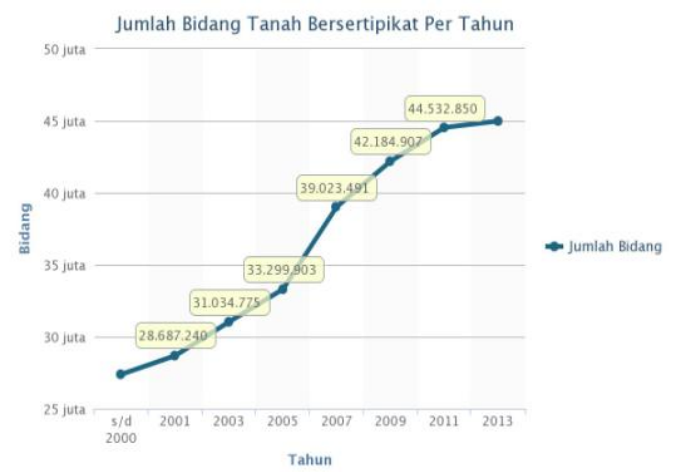

Sumber: www.bpn.co.id

Pada gambar 4.3 terlihat bahwa program yang dilakukan oleh Badan Pertanahan Nasional di Indonesia mengalami peningkatan setiap tahunnya, sejak tahun 2000 sertifikat tanah hanya berjumlah 28.687.240 juta bidang tanah mengalami kenaikan setiap tahunnya hingga tahun 2013 (selama 13 tahun) meningkat menjadi 44.532 .850 juta jumlah bidang yang telah mendapat sertifikasi hak tanah.

\section{Gambar 4.4 Target dan Realisasi Kegiatan Sertifikasi Tanah Petani}

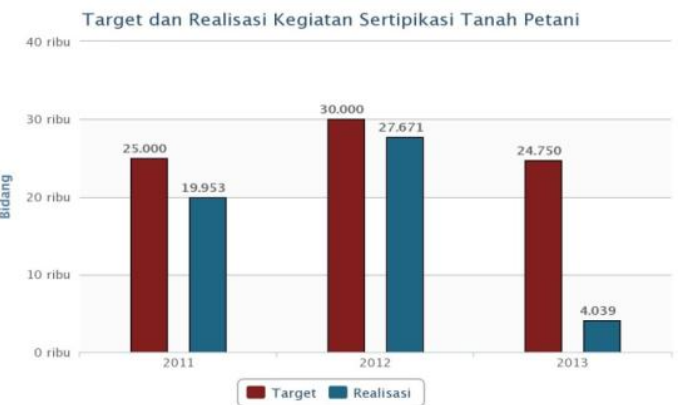

Sumber: www.bpn.co.id

Pada gambar 4.4 menggambarkan tentang realisasi dan target yang dilakukan oleh Badan Pertanahan Nasional di Indonesia, terlihat pada tahun 2011 target 25.000 bidang tanah tidak tercapai, hanya 19.953 ribu bidang yang tercapai untuk disertifikasi hak kepemilikan atas tanah, hal yang sama juga terulang pada tahun 2012 dimana target tidak dapat direalisasikan, namun hanya selisisih 2.329 untuk mencapai target 30.000 
bidang tanah. Sedangkan pada tahun 2013 realisasi mengalami penurunan dalam mencapai target yang telah dibuat, dapat kita lihat pada gambar diatas diagram merah (target) sebesar 24.750 ribu bidang, sedangkan realisasi yang tercapai hanya 4.093 (diagram biru). Program sertifikasi tanah terus dilakukan oleh Badan Pertanahan Nasional di Indonesia demi menata kembali distribusi lahan yang adil di Indonesia.

Tanah sebagai bagian dari bumi disebutkan dalam pasal 4 ayat (1) UUPA, yaitu "Atas dasar hak menguasai dari negara sebagai yang dimaksud dalam pasal 2 ditentukan adanya macam-macam hak atas permukaan bumi, yang disebut tanah, yang dapat diberikan kepada dan dipunyai oleh orang-orang, baik sendiri maupun bersama-sama dengan orang-orag lain serta badan-badan hukum”. Yang dimaksud dengan hak atas tanah adalah hak yang memberi wewenang kepada pemegang haknya untuk mempergunakan atau mengambil manfaat dari tanah yang dimilikinya. Dengan demikian jelaslah bahwa perkataan "mengambil manfaat" mengandung pengertian bahwa hak atas tanah itu dipergunakan untuk kepentingan lahan perkebunan (Santoso, 2005, hal. 10).

Di negara kita, selain tanah milik perorangan dikenal pula tanah untuk kepentingan bersama (tanah desa). Tanah desa dianggap sebagai modal bersama, untuk diusahakan secara bersama demi kepentingan para anggota masyarakat desa itu. Untuk itu setiap warga memiliki hak untuk menguasai tanah tersebut, hak ini sering disebut hak ulayat . karena mengerjakan tanah yang tetap, lambat laun timbul hubungan yang lebih erat dan bersifat tetap antara penggarap dengan tanah garapannya. Kemudian timbul hak-hak yang lebih erat pula misalnya semua hak mencari untung/ hak mengerjakan menjadi hak milik (Mubyarto, 1995, hal. 97).

Tabel 4.1 Hukum Tanah di Indonesia dan Pandangan Abu Ubaid

\begin{tabular}{|c|c|}
\hline Hukum tanah di Indonesia & $\begin{array}{l}\text { Pandangan Abu Ubaid terhadap } \\
\text { tanah }\end{array}$ \\
\hline $\begin{array}{l}\text { a. Pasal } 4 \text { ayat (1) UUPA, yaitu } \\
\text { "Atas dasar hak menguasai } \\
\text { dari negara sebagai yang } \\
\text { dimaksud dalam pasal } 2 \\
\text { ditentukan adanya macam- } \\
\text { macam hak atas permukaan } \\
\text { bumi, yang disebut tanah, } \\
\text { yang dapat diberikan kepada }\end{array}$ & $\begin{array}{l}\text { f. Tanah yang ditinggalkan } \\
\text { penghuni/penggarap dalam } \\
\text { waktu yang lama, maka } \\
\text { keputusan hukum tanah itu } \\
\text { diserahkan kepada kepala } \\
\text { negara. } \\
\text { g. Tanah yang mati (tidak digarap) } \\
\text { tidak ada seseorang yang }\end{array}$ \\
\hline
\end{tabular}


dan dipunyai oleh orangorang, baik sendiri maupun bersama-sama dengan orangorang lain serta badan-badan hukum".

b. untuk mendapatkan hak atas tanah tersebut diperlukan suatu permohonan kepada negara dan apabila persyaratan dianggap telah memenuhi dan permohonan dikabulkan maka Badan atau Pejabat Tata usaha negara yang berwenang untuk itu melakukan tindakan hukum berupa menerbitkan Keputusan Pemberian Hak Atas Tanah kepada pemohon.

c. PMPA No. 2 tahun 1962 tentang Penegasan Konversi Dan Pendaftaran Hak-Hak Indonesia, merupakan bentuk adanya pengakuan oleh negara terhadap hak-hak rakyat baik hak kepemilikan yang diatur menurut hukum perdata barat ( BW) maupun hak-hak tanah adat.

d. selain tanah milik perorangan dikenal pula tanah untuk kepentingan bersama (tanah desa)

e. dalam hukum modern penyelesaian sengketa tanah dilakukan oleh lembaga peradilan yang memberikan keputusan, sedangkan hukum adat menyelesaikan dengan mendamaikan tanpa mengadili atau memutuskan. mengelolanya dan tidak dimiliki orang Islam maupun kafir, status tanah diserahkan kepada kebijakan pemimpin.

h. Negara berhak menguasai tanah yang mati, tandus, tidak terurus, tidak ada pemiliknya dan tidak dimanfaatkan dengan membersihkannya, mengairi, mendirikan bangunan dan menanam kembali benih-benih kehidupan pada tanah tersebut. dengan menjadikannya milik umum dan manfaatnya diserahkan untuk kemaslahatan umat.

i. Tanah akan menjadi hak milik bagi orang yang mau menghidupkan tanah mati dan mendiaminya.

j. Jika telah melewati masa tiga tahun dan tidak menempati tanah yang telah diberikan negara kepadanya, kepala Negaralah yang memutuskan untuk menyerahkan kepada yang lain, yang mampu dan bisa menempati dan menggarap tanah tersebut.

k. Pemerintah tidak boleh memberikan tanah yang produktif kepada orang lain, karena tanah tersebut bisa menabah devisa negara.

l. Jika terjadi sengketa lahan/tanah maka keputusan ada pada pemimpin atau kepala negara

Dari tabel diatas dapat kita lihat bahwa adanya persamaan dan perbedaan dalam hukum tanah untuk masyarakat dalam mengelolanya menjadi lahan perkebunan. Jelas terlihat bahwa negara tidak mempunyai hak memanfaatkan sendiri sebagai milik perseorangan atas tanah, 
bilamana masyarakat umum memerlukan untuk memakai tanah itu. Negara hanya mengatur dengan Undang-Undang.

\subsection{Kesenjangan Dalam Kepemilikan Lahan Perkebunan}

Menurut Kamus Besar Bahasa Indonesia (KBBI) arti kata kesenjangan adalah perihal yang bersifat senjang, ketidakseimbangan, jurang pemisah. Contohnya adalah antara orang kaya dan orang miskin. Kesenjangan itu secara umum dapat dibedakan dalam dua bentuk, yaitu kesenjangan struktural dan kesenjangan kultural.

Kesenjangan struktural adalah kesenjangan yang terjadi antara masyarakat dalam suatu daerah dengan masyarakat di daerah lain (di sebut juga kesenjangan daerah), atau antara suatu kelas sosial dengan kelas sosial yang lain (kesenjangan kelas) adapaun kesenjangan kultural adalah kesenjangan yang disebabkan oleh perbedaan sikap dalam memandang materi, bunga bank, pendidikan, etos kerja, dan sebagainya. Oleh karena perbedaan sikap itu cenderung mengikuti batas-batas etnis, maka kesenjangan kultural juga cenderung muncul dalam kesenjangan etnis.

Satu faktor penyebab kemiskinan disektor pertanian adalah rendahnya produktifitas disektor tersebut dan hal ini salah satunya disebabkan oleh distribusi lahan pertanian yang semakin timpang. Ketimpangan penguasaan lahan pertanian terjadi di Indonesia sudah sejak lama. Program Land reform dilaksanakan pada pertengahan tahun 1960an oleh pemerintahan pada masa itu, namun program ini tidak berhasil mengatasi masalah ketimpangan penguasaan lahan ini seiiring dengan perubahan sistem politik dan ekonomi pada masa rezim orde baru.

Sebuah realita menunjukkan bahwa pertanian di Indonesia didominasi oleh patani kecil (petani gurem). Petani gurem adalah petani dengan luas lahan garapan kurang dari 0,5 ha. Pada tahun 1983 jumlah petani gurem sekitar 46,2 persen dari keseluruhan petani. Duapuluh tahun kemudian, yaitu tahun 2003, jumlah petani gurem meningkat menjadi 56,4 persen (www.spi.co.id).

Distribusi kepemilikan lahan sangat memerlukan peran pemerintah dalam menetapkan kebijakan atau aturan yang berpihak kepada pemenuhan kebutuhan dan hak-hak masyarakat setempat sebagai petani.

Tindakan pemerintah yang lebih mengutamakan kepentingan pendapatan negara yang salah satunya bersumber pada produksi perkebunan. Yang membuat pemerintah melupakan musyawarah dengan masyarakat adat atau setempat sehingga menyebabkan hilangnya hak-hak penduduk penggarap atas tanah-tanah yang disediakan bagi mereka. Perusahaan perkebunan yang memiliki Hak Guna Usaha (HGU) dengan 
lahan yang luas menganggap dirinya lebih berwenang daripada petani karena merasa bahwa perusahaan perkebunan adalah Perusahaan Negara (BUMN) sehingga memperoleh dukungan dan pengakuan dari aparat pemerintah (Limbong, 2012, hal. 356).

Penjelasan diatas menunjukkan bahwa kesenjangan distribusi lahan terjadi antara masyarakat/ petani yang memiliki lahan kecil dan perusahaan perkebunan yang memiliki Hak Guna Usaha dengan lahan yang luas. Sedangkan jika kita lihat dalam kitab Al-Amwal halaman 367. Abu Ubaid memaparkan hadist dari Ibnu Abbas bahwa tatkala Rasulullah tiba di Madinah, maka penduduk madinah telah menyerahkan seluruh tanah kepada Rasulullah sehingga beliau dapat mengelola dan mengurusnya sesuai dengan kebijakannya. Lalu Rasulullah mengkaplingkan tanah itu kepada Bilal. Dan Rasulullah tidak pernah mengkaplingkan tanah kepada seseorangpun terkecuali berdasarkan keridhaan dan keikhlasan mereka.

Kesenjangan dalam kepemilikan lahan perkebunan dapat diselesaikan atau diminimalisirkan apabila kebijakan pemerintah dalam mendistribusikan tanah sudah merata dan adil (mementingkan pemenuhan hak petani setempat/ yang telah lama hidup didaerah tersebut) seperti kebijakan Rasulullah dalam pengkaplingan tanah yang mengutamakan keridhaan dan keikhlasan ummatnya.

\subsection{Proses Menurunkan Kesenjangan Dikalangan Petani}

Kesenjangan yang terjadi menyebabkan banyaknya konflik lahan perkebunan semakin meningkat dan kunjung mendapat solusi atau penyelesaian. Kemudian pemerintah membentuk Badan Otoritas Sengketa Agraria, yang memiliki kewenangan tidak hanya sekedar penyelesaian sengketa/konflik agraria tapi juga memiliki kewenangan melaksanakan reforma agraria, memiliki konsep pembagunan petani dan pertanian. Penataan kembali struktur agraria yang timpang, pendistribusian tanah kepada petani tak bertanah dan rakyat miskin lainnya melalui program pembaruan agraria (land reform).

Banyak penelitian menyimpulkan bahwa reformasi tanah sebagian besar gagal. Kasus yang paling sukses adalah Jepang setelah perang dunia kedua, Taiwan setelah menyingkirnya pemerintahan nasionalis dari daratan (mainland) sejak revolusi komunis, dan Korea Utara setelah perang Korea, hal ini dikarenakan adanya beberapa perkecualian (Lynn,2003,hlm.8). Selain land reform untuk menurunkan kesenjangan dalam kepemilikan lahan, pemerintah juga mengeluarkan Keppres (Keputusan Presiden) No.55 Tahun 1993 yaitu tidak dikenal lagi istilah 
pembebasan tanah, istilah pembebasan tanah telah diganti dengan pelepasan atau penyerahan hak atas tanah. Pengadaan tanah yang diatur dalam Keppres No.55 tahun 1993 ini semata-mata hanya digunakan untuk pemenuhan kebutuhan tanah bagi pelaksanaan pembangunan untuk kepentingan umum, yang dilaksanakan oleh pemerintah dengan cara pelepasan atau penyerahan hak atas tanah. Pengadaan tanah selain untuk pelaksanaan pembangunan untuk kepentingan umum oleh pemerintah dilaksanakan dengan cara jual beli, tukar menukar, atau cara lain yang disepakati secara sukarela oleh pihak-pihak yang bersangkutan.

Namun, dalam Keppres No.55 Tahun 1993 tidak adanya sanksi jika terjadi penyelewengan peruntukkan penggunaan tanah ataupun adanya manipulasi data penggunaan tanah yang seharusnya untuk kepentingan umum yang dilakukan oleh seorang pejabat yang mengatasnamakan kepentingan umum tetapi untuk kepentingan swasta. Atau bagaimaa jika proyek pembangunan itu tidak jadi dilaksanakan, sedang tanahnya sudah dilepaskan/ dibebaskan, apakah tanahnya dekembalikan kepada pemilik semula. lalu bagaimana dengan ganti kerugiannya yang belum dibayarkan (Sutedi, 2007, hal. 154-160).

Sedangkan jika kita melihat hukum dan cara Abu 'Ubaid memberikan solusi atas kesenjangan kepemilikan lahan sangat berbeda dengan kebijakan pemerintah di Indonesia, salah satunya adalah kejelasan atas tanah yang ditinggal oleh penggarapnya yaitu selama tiga tahun kemudian pemerintah mengambil hak kembali atas tanah yang terlantar tersebut. Pemerintah mempunyai wewenang untuk memberikan tanah tersebut kepada penggarap baru yang mau menghidupkan tanah tersebut menjadi lebih produktif. Lebih jelasnya bisa kita lihat dibawah ini mengenai hukum pengkaplingan dan pengelolaan tanah menurut Abu 'Ubaid.

\section{ANALISIS DAN PEMBAHASAN}

\subsection{Peran Pemerintah Dalam Distribusi Tanah atau Lahan Perkebunan Menurut Abu 'Ubaid Al-Qasim Bin Salam}

Abu Ubaid menyusun beberapa hadist yang berkenaan dengan hak rakyat terhadap pemimpin dan hak pemimpin terhadap rakyat dalam kitab Al-amwal, salah satunya yaitu Dari al-Harats bin Yazid al-Hadhrami bahwa Abu Dzar bertnya kepada Rasulullah mengenai kepemimpinan. Lalu Rasulullah bersabda kepadanya, "Kepemimpinan adalah sebuah amanah dan akan mendatangkan penyesalan serta kerugian pada hari kiamat kelak, kecuali orang yang memegangnya sesuai dengan haknya dan melaksaakan tugas yang telah di bebankan kepadanya". Kemudian 
hadist yang lain menyebutkan bahwa sesungguhnya seorang khalifah harus menerapkan hukum-hukum yang terdapat di dalam kitab Allah. Juga, harus menyayangi dan memperhatikan rakyatnya seperti sikap kasih sayang seorang terhadap keluarganya. Lalu Ka'ab al-ahbar berkata "itulah yang benar"(Ubaid,2006,hlm.61,64)

Kemudian dalam Kitab Al-Amwal hal.256: Khalifah Umar Abdul mengirim surat kepada Hamid bin Abdurrahman, gubernur Irak, agar membayar sетиа gaji dan hak rutin di propinsi itu. Dalam surat balasannya, Abdul Hamid berkata, - Saya sudah membayarkan semua gaji dan hak mereka tetapi di Baitul Mal masih terdapat banyak uang. Umar memerintahkan, Carilah orang yang dililit utang tapi tidak boros. Berilah dia uang untuk melunasi utangnya. Abdul Hamid kembali menyurati Umar, Saya sudah membayarkan utang mereka, tetapi di Baitul Mal masih banyak uang. Umar memerintahkan lagi, "Kalau ada orang lajang yang tidak memiliki harta lalu dia ingin menikah, nikahkan dia dan bayarlah maharnya. Abdul Hamid sekali lagi menyurati Umar, Saya sudah menikahkan semua yang ingin nikah tetapi di Baitul Mal ternyata masih juga banyak uang. Akhirnya, Umar memberi pengarahan, Carilah orang yang biasa membayar jizyah dan kharaj. Kalau ada yang kekurangan modal, berilah pinjaman kepada mereka agar mampu mengolah tanahnya. Kita tidak menuntut pengembaliannya kecuali setelah dua tahun atau lebih.

Dari beberapa hadist dan perkataan Abu Ubaid di atas tampak jelas bahwa doktrin Abu Ubaid adalah pembelaan terhadap pelaksanaan distribusi kekayaan secara adil dan merata berdasarkan prinsip-prinsip keadilan fiskal dengan sebaik dan sesempurna mungkin. Dengan kata lain, Abu Ubaid ingin menyatakan bahwa segala kebijakan yang hanya menguntungkan sekelompok masyarakat dan membebani sekelompok masyarakat lainnya harus dihindari negara semaksimal mungkin. Pemerintah harus mengatur harta kekayaan negara harus selalu dimanfaatkan demi kepentingan bersama dan mengawasi hak kepemilikan pribadi agar tidakdisalah gunakan sehingga mengganggu serta mengurangi manfaat bagi masyarakat umum.

Abu Ubaid tidak memberikan pandangannya pada suatu kasus jika ia tidak menemukan landasannya di dalam al $\neg$ Qur'an dan hadis, walaupun begitu ia memberikan tempat bagi mayashid asy-syari'ah dalam melakukan ketetapan hukum-hukum. Sehubungan dengan ini, manfaat bagi publik (ulmuslahah al-'ammah) merupakan penentu akhir dalam memilih alternatif dari ijtihad. Ia juga membagi keputusan hukum yang kontroversial menjadi terakreditasi dan tidak terakreditasi dengan 
merujuk pada otoritas dan ulama yang ternama saja. Preferensi Abu Ubaid terhadap pendapat para ulama yang kontroversial yang telah lama membuktikan bahwa ia memberi ruang pada ta 'amul (hukum adat atau tradisi).

Abu Ubaid rnengakui adanya kepemilikan pribadi dan publik karena pendekatan terhadap kepemilikan tersebut sudah sangat dikenal dan dibahas secara luas oleh banyak ulama. Sesuatu yang baru dalam hubungan antara kepemilikan dengan kebijakan perbaikan pertanian ditemukan oleh Abu Ubaid secara implisit. Menurutnya, kebijakan pemerintahan seperti itu terhadap tanah gurun dan deklarasi resmi terhadap kepemilikan individual dari tanah tandus atau tanah yang sedang diusahakan kesuburannya atau diperbaiki sebagai insentif untuk meningkatkan produksi pertanian, maka tanah yang diberikan dengan persyaratan untuk ditanami dibebaskan dari kewajiban membayar pajak. Jika dibiarkan sebagai insentif untuk meningkatkan produksi pertanian, maka tanah yang diberikan dengan persyaratan untuk ditanami dibebaskan dari kewajiban membayar pajak, jika dibiarkan menganggur selama tiga tahun berturut-turut akan didenda dan kemudian akan dialihkan kepemilikannya oleh Imam. Bahkan tanah gurun yang termasuk dalam himu (tanah pribadi), pribadi dengan maksud untuk direklamasi jika tidak ditanami dalam periode yang sama dapat ditempati oleh orang lain dengan proses yang sama. Pemulihan yang sebenarnya adalah pada saat tanah tersebut ditanami setelah diairi, manakala tandus, kering atau rawa-rawa.

\subsection{Hukum Pengkaplingan Tanah Menurut Abu 'Ubaid}

Rasulullah bersabda, "Tanah 'Adiy (tanah yang lama tidak dikelola lagi yang diluar pengelolan dan hak kepemilikan) adalah milik Allah dan Rasul-Nya. Kemudian dijadikan sebagai milik kamu." Ada seseorang yang bertanya, "apa yang dimaksud dengan sabda beliau, "Kemudian dijadikan sebagai milik kamu?" perawi menjawab, "Kalian mengkapling tanah itu kepada umat manusia"

Meneurut $\mathrm{Abu}$ Ubaid, penjelasan hadist diatas merupakan penafsiran dan penjelasan terhadap tanah yang boleh dikapling dan yang tidak boleh dikapling. Yang dimaksudkan denga $a l$ - $A d y$ adalah setiap tanah yang sebelumnya didapati penghuni, lalu mereka punah sehingga tidak ada seorang manusia pun yang tersisa dari kalangannya. Oleh karena itu, status tanah seperti ini diserahkan kepada kebijakan dan keputusan seorang pemimpin. Demikian juga setiap tanah mati, yang 
tidak pernah dikelola oleh seorang pun dan dia juga tidak pernah dimiliki oleh muslim dan juga non muslim.

Sekarang sudah jelas bahwa pengkaplingan tanah hanya bisa terjadi pada tanah yang tidak ada pemilik sebelumnya. Apabila kondis tanah itu belum ada pemiliknya maka pengurus dan penentuan hukumnya diserahkan kepada seorang pemimpin atau pemerintah.

Abu Ubaid juga membahas mengenai hukum tanah yang banyak digenangi air, apabila ada seseorang yang bertempat tinggal dan berkebun diatas tanah tersebut dan membuka jalan kepada orang lain supaya dapat bercocok tanam dan memanfaatkanya. Kemudian ada satu kaum yang mencoba mengatasinya dengan membuang air diatas permukaan tanah tersebut dengan cara membuat saluran atau mengeringkan tanah yang basah sehingga tanah mampu meresap air yang mengenanginya. Oleh karena itu, sehingga sama seperti tanah yang telah dikelolanya dan ia menjadi hak milik baginya.

Untuk masalah pada masa sekarang ini adalah banyaknya kasus tumbang tindih kepemilikan atas tanah/ lahan perkebunan yang ada, sebelumnya pemberian kaplingan tanah oleh pemimpin desa atau pemerintah kemudian orang tersebut meninggalkan tanah/ lahan itu, pada akhirnya datang orang kedua menempati dan berkebun pada tanah tersebut sehingga mengakui tanah tersebut menjadi hak miliknya. Masalah terjadi pada saat orang pertama datang kembali dan mengakui haknya atas tanah tersebut. Pemerintah kemudian membuat Peraturan Pemerintah (PP) No.12 Tahun 2012 tentang perlindungan lahan pertanian, namun peraturan ini tidak mendapat perubahan signifikan terhadap masalah diatas. Untuk mewujudkan peraturan tersebut Badan Pertanahan Nasional (BPN) membuat konsep sertifikasi tanah Petani, konsep ini akan memberikan kejelasan atas hak milik tanah seseorang sehingga tidak ada lagi yang mengakui tanah tersebut. Namun jika tanah tersebut dijual, hak kepemilikannya juga harus diubah (pendaftaran seritifikasi kembali untuk mengubah nama kepemilikan).

\subsection{Hukum Pengelolaan Tanah, Pemberian Tanda Hak Milik, dan Pengalihan Hak Atas Orang Yang Pernah Mengelolanya}

Di negara kita, selain tanah milik perorangan dikenal pula tanah untuk kepentingan bersama (tanah desa). Tanah desa dianggap sebagai modal bersama, untuk diusahakan secara bersama demi kepentingan para anggota masyarakat desa itu. Untuk itu setiap warga memiliki hak untuk menguasai tanah tersebut, hak ini sering disebut hak ulayat . karena mengerjakan tanah yang tetap, lambat laun timbul hubungan yang lebih 
erat dan bersifat tetap antara penggarap dengan tanah garapannya. Kemudian timbul hak-hak yang lebih erat pula misalnya semua hak mencari untung/ hak mengerjakan menjadi hak milik (Mubyarto, 1995, hal. 97).

Salah satu hal yang menyebabkan terjadinya konflik lahan perkebunan pada masa sekarang ini adalah karena hak menguasai oleh negara atas tanah yang sesunguhnya harus dipergunakan untuk mendorong kemandirian dan kesejateraan rakya justru lebih banyak diberikan kepada badan hukum dalam bentuk Hak Guna Usaha (HGU). Sementara di lain pihak tidak ada kepastian hukum terhadap hak masyarakat (lokal dan adat) atas sumberdaya lahan, baik untuk perkebunan maupun fungsi lain.

Pemerintah perlu melakukan pemetaan hak ulayat atau kepemilikan tanah adat sesuai amanat Undang-Undang No. 21 Tahun 2001. Jika pemetaan dilakukan, maka jelas mempermudah juga prosesproses penyelesaian masalah tanah adat. Investor tidak langsung berhubungan dengan pemerintah dan memperoleh surat izin untuk melakukan pekerjaannya di atas tanah adat di daerah Sumatera, tanpa persetujuan lebih awal dari mereka. Artinya, pemerintah sebagai penyelenggara negara, harus menjamin pemenuhan hak masyarakat adat juga. Dalam hal ini tidak seenaknya saja memberikan izin kepada investor dengan mengatasnamakan pembangunan nasional dan slogan 'tanah negara'.

Menurut Abu Ubaid mengenai hukum pengelolaan tanah atau lahan perkebunan yaitu dibagi menjadi tiga jenis. Pertama, seorang mendatangi kearah tanah yang mati lalu dia mengelolanya. Kemudian datang orang lain kedaerah itu, lalu dia bercocok tanam dan mendirikan bangunan di atas tanah kosong itu. Orang tersebut bertujuan mengambil alih hak pengelolaan dan pembangunan yang pernah dilakukan oleh orang sebelumnya. Kedua, pemimpin memberikan kaplingan tanah kepada seorang lelaki, maka tanah tersebut menjadi hak milik si penerima kaplingan tanah. Akan tetapi, dia melalikan dan mengabaikan pengelolaa dan pembangunannya sehingga datang orang lain, lalu orang baru itu mengelola dan membangunnya karena mengira bahwa tanah tersebut tidak ada pemiliknya. Ketiga, seseorang memberikan tanda atau membuat menara di atas tanah kosong, atau menggali lubang di sekelilingnya, atau menggali saluran air penghalang banjir dan lain-lain, yang bisa dijadikan sebagai tanda hak kepemilikan. Kemudian dia meninggalkannya dengan keadaan seperti itu dan orang lain pun enggan untuk mengelola tanah 
tersebut karena terdapat hak milik dan tanda pengakuan milik orang lain (Al-Qasim, 2009, hal. 371).

Mengenai jenis pertama, menurut Abu Ubaid hukumnya adalah orang yang datang kedua harus memberikan ganti rugi harga bangunannya kepada pemilik pertama. Sedangkan megenai jenis kedua pengelolaan tanah, maka pemimpin memberikan kaplingan tanah kepada seorang lelaki lalu dia meninggalkannya tanpa membangun apapun di atasnya, kemudia datang orang lain bercocok tanam di atas tanah tersebut. Tidak lama kemudian, orang yang menerima kaplingan tanah mengajukan persengketaan ke hadapan pengadilan, maka hasil dari pengelolaan tanah tersebut dihargai oleh pemilik kaplingan dan tanah tersebut menjadi miliknya, atau menjual tanah kaplingan kepada orang yang telah mengelola tanah tersebut kemudia tanah tersebut menjadi milik orang tersebut. Sedangkan menurut hukum jenis pengelolaa tanah yang ketiga, area yang mesti dipertahankan dan terlarang telah dijadikan sebagai hak milik si penggali, karena dia merupakan orang pertama yang mengelola tanah kosong/ tanah mati.

Namun pada sebagian hadist yang telah diriwayatkan oleh Umar telah menerangkan bahwa masa dan waktu meninggalkan tanah itu hanya selama tiga tahun. Setelah itu, mengenai status tanah itu diserahkan kembali kepada pemimpin atau pemerintah.

\section{KESIMPULAN}

Dari uraian pada bab-bab sebelumnya dapat disimpulkan hal-hal sebagai berikut:

1. Abu ubaid mengakui adanya kepemilikan pribadi dan kepemilikan publik. dalam hal ini kepemilikan menurut pemikiran abu Ubaid adalah mengenai hubungan anatara kepemilikan dengan kebijakan perbaikan pertanian. Secara implisit Abu Ubaid mengemukakan bahwa kebijakan pemerintahan, seperti iqta' (enfeoffment) tanah gurun dan deklarasi resmi terhadap kepemilikan individual atas tanah tandus yang disuburkan, sebagai insentif untuk meningkatkan produksi pertanian. Maka tanah yang diberikan dengan persyaratan untuk diolah dan dibebaskan dari kewajiban membayar pajak, jika dibiarkan menganggur selama tiga tahun berturut-turut, akan didenda dan kemudian dialihkan kepemilikannya oleh penguasa. Bahkan tanah gurun yang termasuk hima pribadi dengan maksud untuk direklamasi, jika tidak ditanami dalam periode yang sama, dapat ditempati oleh orang lain melalui proses yang sama. 
2. Melihat hukum dan cara Abu 'Ubaid memberikan solusi atas kesenjangan kepemilikan lahan sangat berbeda dengan kebijakan pemerintah di Indonesia, salah satunya adalah kejelasan atas tanah yang ditinggal oleh penggarapnya yaitu selama tiga tahun kemudian pemerintah mengambil hak kembali atas tanah yang terlantar tersebut. Pemerintah mempunyai wewenang untuk memberikan tanah tersebut kepada penggarap baru yang mau menghidupkan tanah tersebut menjadi lebih produktif.

3. Permasalahan yang menjadi perhatian khusus oleh pemerintah adalah mengenai lahan mati yang diakibatkan oleh bekas perkebunan kelapa sawit atau karet selama bertahun-tahun lamanya (10 sampai 20 tahun) harus segera digunakan untuk menambah pendapatan petani kecil, kemudian kepemilikan tanah/ lahan yang tumpang tindih, serta kepemilikan tanah antara pihak swasta dan Negara. Badan Pertanahan Nasional Indonesia mengeluarkan kebijakan Reforma Agraria yaitu Pembaruan agraria mencakup suatu proses yang berkesinambungan berkenaan dengan penataan kembali penguasaan, pemilikan, penggunaan dan pemanfaatan sumberdaya agraria, dilaksanakan dalam rangka tercapainya kepastian dan perlindungan hukum serta keadilan dan kemakmuran bagi seluruh rakyat Indonesia (pasal 2 TAP MPR RI Nomor IX/MPR/2001).

4. Dalam kitab Al-Amwal menjelaskan bahwa Tanah akan menjadi hak milik bagi orang yang mau menghidupkan tanah mati dan mendiaminya. Jika telah melewati masa tiga tahun dan tidak menempati tanah yang telah diberikan negara kepadanya, kepala Negaralah yang memutuskan untuk menyerahkan kepada yang lain, yang mampu dan bisa menempati dan menggarap tanah tersebut. Pemerintah tidak boleh memberikan tanah yang produktif kepada orang lain, karena tanah tersebut bisa menabah devisa negara. Dan jika terjadi sengketa tanah/ lahan perkebunan maka keputusan ada pada pemimpin atau kepala negara.

5. Pemikiran Abu Ubaid mengenai tanah/ lahan perkebunan dengan kebijakan pemerintah yang ada di Indonesia memiliki kesamaan dan perbedaan. Adapun kesamaannya yaitu, mengenai distribusi lahan perkebunan bagi petani bahwa dalam hukum di Indonesia mengakui kepemilikan hak atas tanah yang ditandai dengan adaya sertifikas tanah pertanian, sedangkan menurut Abu Ubaid adalah hak tanah bagi petani yang menggarap tanah/ lahan perkebunan yang telah ditunjuk oleh Imam/ Kepala Negara. Perbedaannya 
terletak pada kepmilikan dan hak-hak yang lebih spesifikasi dilakuka oleh Islam, bahwa jika lahan tidak digarap selam tiga tahun berturut-turut, atau tanah mati tidak ada yang mengelolanya maka tanah tersebut menjadi hak negara untuk mengalihkan hak kepada orang lain yang mau menggarap dan menyuburkan tanah itu kembali. Sementara hukum di Indonesia masih umum, dengan tidak memberlakukan waktu untuk pemilik tanah/ lahan perkebunan, dan siapa yang memiliki modal besar akan mudah mendapatkan hak kepemilikan atas tanah yang luas.

\section{DAFTAR PUSTAKA}

Al-Maliki, A. (2001). Politik Ekonomi Islam. Jakarta Timur: Al-Izzah.

Al-Qasim, A. U. (2009). Al-Amwal Ensiklopedia Keuangan Publik. Jakarta: Gema Insani.

Arifin, B. (2005). Pembangunan Pertanian: Paradigma Kebijakan dan Strategi Revitalisasi. Jakarta: PT Grasindo.

Ash Shadr, M. B. (2008). Buku Induk Ekonomi Islam Iqtishaduna. Jakarta: Zahra.

Denny, J. (2006). Napak Tilas Reformasi Politik Indonesia. Yogjakarta: LKIS.

http://karyaku-informasi.blogspot.com/2012/03/advanced-micro-devicesamd.html. (t.thn.).

Huda, N., \& Muti, A. (2011). Keuangan Publik Islam Pendekatan AlKharaj (Imam Abu Yusuf). Bogor: Ghalia Indonesia.

Izzan, A., \& Tanjung, S. (2006). Referensi Ekonomi Syariah Ayat-Ayat Al-Qur'an yang Berdimensi Ekonomi. Bandung: PT Remaja Rosdakarya.

Karim, A. (2004). Sejarah Pemikiran Ekonomi Islam. Jakarta: PT Raja Grafin.

Limbong, B. (2012). Pengadaan Tanah Untuk Pembangunan Regulasi, Kompensasi, dan Penegakan Hukum. Jakarta: MP Pustaka Margaretha.

Majid, N. M. (2003). Pemikiran Ekonomi Islam Abu Yusuf. Bogor: Penada.

Maria. (2001). Kebijakan Pertanahan. Jakarta: Kompas.

Mubyarto. (1995). Pengantar Ekonomi Pertanian: Edisi Ketiga. Jakarta: LP3ES.

Rachbini, D. J. (2004). Ekonomi Politik Kebijakan dan Strategi Pembangunan. Jakarta: Granit.

Rahmawati. (2013). Bisnis Indonesia. Bogor: IPB. 
Santoso, U. (2005). Hukum Agraria dan Hak-Hak Atas Tanah. Jakarta: Kencana.

Sumardjono, M. S. (2008). Tanah Dalam Perspektif Hak Ekonomi, Sosial, dan Budaya. Jakarta: PT Kompas Media Indonesia.

Sutedi, A. (2007). Implementasi Prinsip Kepentingan Umum Dalam Pengadaan Tanah Untuk Pembangunan. Jakarta: Sinar Grafika.

Alamat Web :

www.bpn.go.id. (t.thn.).

www.bps.go.id. (t.thn.).

www.indoprogress.com. (t.thn.).

www.spi.co.id. (t.thn.). 